\title{
The Possible Protective Role of N-Acetyl Cysteine against Titanium Dioxide Nanoparticles Intestinal Toxicity in Adult Male Albino Rats
}

\author{
Eman E. Khayal, Dalia M. Amin ${ }^{1}$ and Marwa A. Shabana ${ }^{2}$ \\ ${ }^{1}$ Forensic Medicine and Clinical Toxicology Department, Faculty of Medicine, Zagazig University, Egypt. \\ ${ }^{2}$ Clinical Pathology Department, Faculty of Medicine, Zagazig University, Egypt.
}

\begin{abstract}
Introduction: With extensive applications of nanoparticles including titanium dioxide nanoparticles $\left(\mathrm{TiO}_{2} \mathrm{NPs}\right)$ in different fields, many adverse effects may threat both environmental and medical health. Aim of this work: To evaluate the role of n-acetyl cysteine (NAC) against $\mathrm{TiO}_{2}$ NPs intestinal toxicity in adult albino rats. Material and methods: Fifty adult male albino rats were classified into five groups. Group I: negative control received regular diet and water. Group II: positive control administered $1 \mathrm{ml}$ of $5 \%$ gum acacia solution once a day. Group III: gavaged orally with NAC (100 mg/kg). Group IV: orally gavaged with $\mathrm{TiO}_{2} \mathrm{NPs}(1200 \mathrm{mg} / \mathrm{kg})$ once a day. Group V: orally gavaged once daily with $\mathrm{TiO}_{2} \mathrm{NPs}(1200 \mathrm{mg} / \mathrm{kg})$ and NAC (100 $\mathrm{mg} / \mathrm{kg}$ ). After 6 weeks, all rats were weighed and blood sample were submitted to estimate serum level of citrulline. Then parts of ileum from all rats was dissected and subjected to interleukin 6 (IL6), interleukin 10 (IL10) and tumor necrosis factor (TNF- $\alpha$ ) estimation, histopathological examination and determine the extent of DNA damage by gel electrophoresis. Results: The results revealed that $\mathrm{TiO}_{2}$ NPs induced significant decreases in body weight, and serum level of citrulline with significant increases in IL6, TNF- $\alpha$ and significant decrease IL10 in tissues of ileum. These were associated with histopathological changes in the ileum and DNA damage detected by gel electrophoresis. Co-administration of NAC with $\mathrm{TiO}_{2} \mathrm{NPs}$ provided protection against these changes. Conclusion: $\mathrm{TiO}_{2} \mathrm{NPs}$ exposure causes inflammation in ileum with DNA damage and administration of NAC offers protection against its damaging effects.
\end{abstract}

Key words Ileum; N-acetyl cysteine; Titanium dioxide nanoparticles; Cytokines.

\section{Introduction}

1 Technological advances have helped to decrease the size of particles to less than $100 \mathrm{~nm}$, calling them nanoparticles. With increasing the production and consumption of nanoparticles daily, there are growing opportunities of contact nanoparticles with the environment inducing adverse effects on both environmental and medical health (Shah et al., 2017).

Nanoparticles differ from that of the fine particles as regard physicochemical properties. They have smaller size, large number of atoms on their surface and different surface characteristics, as level of energy. These differences attract more attentions to study adverse effects of nanoparticles (Shi et al., 2013 and Yang et al., 2017).

Titanium dioxide nanoparticles $\left(\mathrm{TiO}_{2} \mathrm{NPs}\right)$ are extensively applied in different fields as in cosmetics, pharmaceuticals and medicine. Their wide use is attributed to their biocompatibility, resistance to corrosion, low cost, whitening, photo catalysis and ease of obtaining in nano sizes (Shakeel et al., 2016).

Exposure to $\mathrm{TiO}_{2} \mathrm{NPs}$ can be occurred by all routes, including inhalation, ingestion, skin applications, and injections (Migdal et al., 2010). After absorption, they are distributed to different body organs as kidneys, liver, lungs, brain, and lymphatic organs producing toxic effects on these organs (Grande and Tucci, 2016).

$\mathrm{TiO}_{2}$ NPs interact with cytoplasmic proteome producing posttranslational modifications, like acetylation and oxidative stress (Sund et al., 2014). On reaching the peri region of nucleus, they interrupt the function of endoplasmic reticulum, and block the nuclear pore or invade the nucleus. Inside the nucleus, they react with DNA (Park et al., 2008) and cause the upregulation of cytokines, oxidative stress, and apoptosis (Gui et al., 2011).

$\mathrm{N}$-acetylcysteine (NAC) is a thiol containing amino acid. It is available as a safe and cheap medication as a mucolytic drug in the 1960 (Youssef et al., 2006; Larsson et al., 2015). Despite cysteine is present naturally in many food types, NAC is not a natural substance. It is a cysteine precursor which is converted to glutathione in the body. This glutathione has the capacity to protect the tissues against bad effects of free oxygen species, so, it is considered as one of the most important antioxidants (Mokhtari et al., 2017). 
NAC is a well known line of treatment in paracetamol toxicity (Waring, 2012), In addition to its antioxidant effects, NAC posses the capacity to suppress release of inflammatory cytokines (Xue et al., 2011). As a result, it can be used as treatment or defense measure in many diseases such as infertility, chronic bronchitis, ulcerative colitis, asthma, alzheimer , and parkinson disease (Mokhtari et al., 2017).

This work was performed to assess the effectiveness of NAC versus $\mathrm{TiO}_{2} \mathrm{NPs}$ intestinal toxicity through detecting the changes in body weight, serum level of citrulline, intestinal tissue levels of interleukin 6 (IL-6), interleukin 10 (IL-10) and tumor necrosis factor (TNF- $\alpha$ ), histopathological changes and DNA damage assay.

\section{Materials and Methods Chemicals}

Titanium dioxide nanoparticles (CAS No is 13463-67$7,21 \mathrm{~nm}$ in size) with purity $\geq 99.5 \%$ was bought from Sigma Company, Egypt. Gum acacia was obtained from El- Nasr Pharmaceutical Chemicals Company, Egypt. It was used as a solvent for $\mathrm{TiO}_{2} \mathrm{NPs}$. NAcetylcysteine (200 mg sachets) was purchased from SEDICO Company, Egypt.

\section{Methods}

Fifty adult male albino rats were bought from the animal breeding house of Faculty of Medicine, Zagazig University weighing 200-210 gm. The rats were housed in suitable cages and supplied with commercial laboratory animal food and water ad libitum. All ethically approved conditions used for animal housing \& handling were considered. Standards for animal care and administration met those required by applicable international laws and regulations (ILAR 1996).

The rats were equally sectioned as following:

- $\quad$-ve control group (I): 10 rats received only regular diet and water for 6 weeks.

- +ve control group (II): 10 rats, each rat orally gavaged by $1 \mathrm{ml}$ of $5 \%$ gum acacia solution once a day for 6 weeks.

- NAC group (III): 10 rats, each rat orally gavaged orally with n-acetyl cysteine (100 $\mathrm{mg} / \mathrm{kg}$ body weight $\{\mathrm{b} . \mathrm{w}\}$ ) dissolved in $1 \mathrm{ml}$ of distilled water once a day for 6 weeks (Jain et al., 2011).

- $\quad \mathrm{TiO}_{2}$ NPs group (IV): 10 rats, each rat gavaged orally with $\mathrm{TiO}_{2}$ NPs (1200 mg/kg b.w) (1/10 LD ${ }_{50}$ ) in $1 \mathrm{ml}$ of $5 \%$ gum acacia solution as a solvent once a day for 6 weeks. Oral $\mathrm{LD}_{50}$ of $\mathrm{TiO}_{2}$ NPs for rats is more than $12,000 \mathrm{mg} / \mathrm{kg}$ body weight (Wang et al., 2007).

- $\mathrm{TiO}_{2} \mathrm{NPs}+\mathrm{NAC}$ group (V): 10 rats, each rat orally recevied NAC $(100 \mathrm{mg} / \mathrm{kg} \quad$ b.w $)$ dissolved in $1 \mathrm{ml}$ of distilled water then $\mathrm{TiO}_{2}$ NPs (1200 mg/kg b.w) dissolved in $1 \mathrm{ml}$ of $5 \%$ gum acacia solution once a day for 6 weeks.

The rats were left without treatment for 24 hours, then they were weighed and venous blood samples were obtained from the retro-orbital plexus according to a method described by Joslin (2009) from all rats of all groups to estimate the serum levels of citralline. Rat Citrulline ELISA kit Cusabio (catalog number CSB-E13414r) was used. Serum citrulline level was measured with a spectrophotometric method at a wave length of $450 \mathrm{~nm}$ and expressed in $\mathrm{nmol} / \mathrm{ml}$.

The anaesthetized rats were, then, sacrificed. Parts of ileum were dissected and used for the following:

- Measuring cytokines levels in ileal tissues: After homogenization of ileal tissues, the sample was centrifuged at $4000 \mathrm{rpm}$ for 10 min then the supernatant was used to estimate the levels of IL-6, IL-10 and TNF- $\alpha$ using an enzyme-linked immunosorbent assay (ELISA) according to a method described by Amsen et al.(2009) and expressed in pg/mg protein.

- Histopathological examination: parts of ileum were fixed with $10 \%$ formalin for preparing 5$\mu \mathrm{m}$ thick sections then stained with hematoxylin and eosin (H\&E) for light microscope examination according to the method described by Horobin and Bancroft (1998).

- DNA damage assay: After homogenization of ileal tissues, the samples were centrifuged at 11,000 rpm for $15 \mathrm{~min}$. The supernatants were taken and divided into two halves. One half was used to detect DNA fragments by gel electrophoresis and the remaining half was used to determine amount of DNA fragmentation by the diphenylamine assay according to the method of Burton (1956) modified by Perandones et al. (1993). Then the percentage of DNA fragmentation in every specimen was calculated and tabulated.

All data were collected and calculated as mean values \pm standard deviations (SD) then statistically analyzed by using SPSS Software program.

\section{Results}

No significant differences were detected between -ve control (I), +ve control (II) and NAC (III) groups respectively $(\mathrm{P}>0.05)$ by ANOVA test as regard mean values of body weight, serum citrulline, tissue levels of IL6, IL10 and TNF- $\alpha$ (Fig 1), morphological changes in ileal tissues and DNA changes, so we used -ve control group (I) as a standard reference for comparison with other treated groups.

\section{Body weight}

Titanium dioxide nanoparticles treated rats (group IV) revealed a significant reduction in body weight in comparison with other groups $(\mathrm{P}<0.001)$. Addition of NAC to $\mathrm{TiO}_{2} \mathrm{NPs}$ (group V) provided significant protection against body weight loss caused by $\mathrm{TiO}_{2}$ NPs $(\mathrm{P}<0.001)$ (Table 1).

\section{Serum citrulline}

Titanium dioxide nanoparticles administration caused significant decrement in serum level of citrulline when compared to the results of other groups $(\mathrm{P}<0.001)$. Serum citrulline level was significantly higher in TiO2 NPs +NAC group (V) compared to TiO2 NPs group (IV). However, this level was 
significantly lower than that of -ve control group (I) $(\mathrm{P}<0.001)$ (Table 2).

Cytokines assay (IL6, IL10 and TNF-a) in ileum In the present work, the rats treated with $\mathrm{TiO}_{2}$ NPs (group IV) showed significant elevations in the ileal tissue levels of IL6 and TNF- $\alpha$ with significant decrement in IL10 compared to other groups $(\mathrm{P}<0.001)$. IL6 and TNF- $\alpha$ were significantly lower and ileal tissue IL10 was significantly higher in the rat group given TiO2 NPs and protected with NAC when compared with group IV treated with only $\mathrm{TiO} 2$ NPs. However, these levels were lower than those of ve control group (I) $(\mathrm{P}<0.001)$ (Table 2).

Histopathology examination of intestinal tissues

The light microscopically examination of ileum of control and NAC groups, showed normal histological appearance (Fig 2). While atrophy of lining mucosa with infiltration of mucosa and submucosa with inflammatory cells in form of lymphocytes, plasma cells and machrophages in
$\mathrm{TiO}_{2}$ NPs intoxicated group were observed (Fig 3). In $\mathrm{TiO}_{2}$ NPs +NAC group (V), NAC use protected lining mucosa of ileal tissues from atrophy with decreased inflammatory cells infiltrate (Fig 4)

\section{DNA damage assay}

In the present study, evaluation of DNA damage by agarose gel electrophoresis (Fig 5) showed no breakage of extracted DNA in control and NAC groups (lane 2, 3, 4). Administration of $\mathrm{TiO}_{2} \mathrm{NPs}$ resulted in fragmentation of extracted DNA appeared as multiple bands (lane 5), while administration of NAC with $\mathrm{TiO}_{2}$ NPs showed no breakage of extracted DNA (lane 6).

By quantitative assessment of DNA fragmentation in tissues of ileum, $\mathrm{TiO}_{2} \mathrm{NPs}$ administration significantly elevated the percentage of DNA fragmentation $(\mathrm{p}<0.001)$ comparing with other groups. Meanwhile, using NAC with $\mathrm{TiO}_{2} \mathrm{NPs}$ in group (V) partially protected the rats from DNA damage induced by $\mathrm{TiO}_{2}$ NPs $(\mathrm{P}<0.001)$ (Table 3).

Table 1: Comparison between -ve control group, $\mathrm{TiO}_{2} \mathrm{NPs}$ group, and $\mathrm{TiO}_{2} \mathrm{NPs}+\mathrm{NAC}$ group as regard body weight.

\begin{tabular}{|l|l|l|l|l|l|}
\hline Index & $\begin{array}{l}\text { Group I } \\
\text { (-ve Control) } \\
\text { mean } \pm \text { SD }\end{array}$ & $\begin{array}{l}\text { Group IV (TiO } 2 \text { NPs) } \\
\text { mean } \pm \text { SD }\end{array}$ & $\begin{array}{l}\text { Group V (TiO } \text { NPs }_{\text {+NAC) group mean }} \\
\pm \text { SD }\end{array}$ & F test & P values \\
\hline $\begin{array}{l}\text { Body weight } \\
\text { (g) }\end{array}$ & $205.025 \pm 3.47$ & $170.65 \pm 9.74 \$$ & $200.27 \pm 3.11 \#$ & 89.29 & $<0.001^{* *}$ \\
\hline
\end{tabular}

Results are expressed as mean $\pm S D$ (Number $=10$ rats/group), g: gram, F=value of ANOVA test, ** highly significant Least significant difference (LSD), \$ Highly significantly compared to control, \#Highly significantly compared to $\mathrm{TiO}_{2} \mathrm{NPS}$

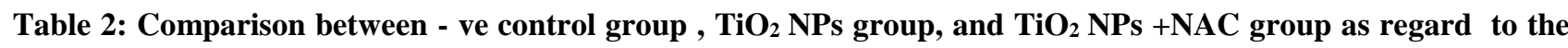
mean values of serum citrulline, and ileal tissue levels of IL6, IL10 and TNF- $\alpha$.

\begin{tabular}{|c|c|c|c|c|c|}
\hline Index & $\begin{array}{l}\text { Group I } \\
\text { (-ve Control) } \\
\text { mean } \pm \text { SD }\end{array}$ & $\begin{array}{ll}\text { Group } & \text { IV } \\
\left(\mathrm{TiO}_{2} \mathrm{NPs}\right) & \\
\text { mean } \pm \text { SD } & \end{array}$ & $\begin{array}{l}\text { Group } \mathrm{V}\left(\mathrm{TiO}_{2} \mathrm{NPs}\right. \\
+\mathrm{NAC}) \text { group mean } \\
\pm \mathrm{SD}\end{array}$ & F test & $P$ values \\
\hline $\begin{array}{l}\text { Serum Citrulline } \\
(\mathrm{nmol} / \mathrm{ml})\end{array}$ & $42.55 \pm 2.22$ & $19.93 \pm 1.52 \$$ & $30.62 \pm 1.05 \$ \#$ & 459.36 & $<0.001^{* *}$ \\
\hline $\begin{array}{ll}\text { IL6 } & \text { (pg/mg } \\
\text { protein) }\end{array}$ & $30.68 \pm 0.94$ & $95.13 \pm 3.02 \$$ & $47.45 \pm 0.91 \$ \#$ & 89.29 & $<0.001^{* *}$ \\
\hline $\begin{array}{ll}\text { IL10 } & \text { (pg/mg } \\
\text { protein) }\end{array}$ & $13.51 \pm 0.088$ & $6.62 \pm 0.243 \$$ & $11.63 \pm 0.088 \$ \#$ & 5092.84 & $<0.001 * *$ \\
\hline $\begin{array}{ll}\text { TNF- } \alpha & \text { (pg/mg } \\
\text { protein) } & \end{array}$ & $0.99 \pm 0.056$ & $4.52 \pm 0.52 \$$ & $1.99 \pm 0.039 \$ \#$ & 362.43 & $<0.001^{* *}$ \\
\hline
\end{tabular}

Results are expressed as mean $\pm S D$ (Number $=10$ rats/group), $\mathrm{pg} / \mathrm{mg}$ protein: picogram $/ \mathrm{milligram} \mathrm{protein} \mathrm{nmol} / \mathrm{ml}$ nanomole/ milliter, F=value of ANOVA test, ** highly significant, Least significant difference (LSD), \$ Highly significantly different compared to control, \#Highly significantly different compared to $\mathrm{TiO}_{2} \mathrm{NPs}_{\text {. }}$

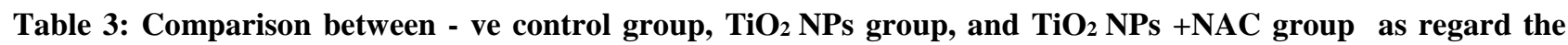
mean values of fragmented DNA\% in ileal tissues.

\begin{tabular}{|c|l|l|l|l|l|}
\hline Index & $\begin{array}{l}\text { Group I } \\
\text { (-ve Control) } \\
\text { mean } \pm \text { SD }\end{array}$ & $\begin{array}{l}\text { Group IV } \\
\left(\mathbf{T i O}_{2} \mathbf{N P s}\right) \\
\text { mean } \pm \text { SD }\end{array}$ & $\begin{array}{l}\text { Group } \\
\left(\mathbf{T i O}_{2} \text { NPs +NAC) }\right. \\
\text { mean } \pm \text { SD }\end{array}$ & F test & P values \\
\hline $\begin{array}{r}\text { Fragmented } \\
\text { DNA \% }\end{array}$ & $4.03 \pm 0.135$ & $53.68 \pm 4.3 \$$ & $18.82 \pm 0.71 \$ \#$ & 1023.6 & $<0.001^{* *}$ \\
\hline
\end{tabular}

Results are expressed as mean $\pm S D$ (Number $=10$ rats/group), \% percentage, $F=v a l u e$ of ANOVA test, ** highly significant, Least significant difference (LSD), \$ Highly significantly different compared to control , \#Highly significantly different compared to $\mathrm{TiO}_{2} \mathrm{NPs}$. 


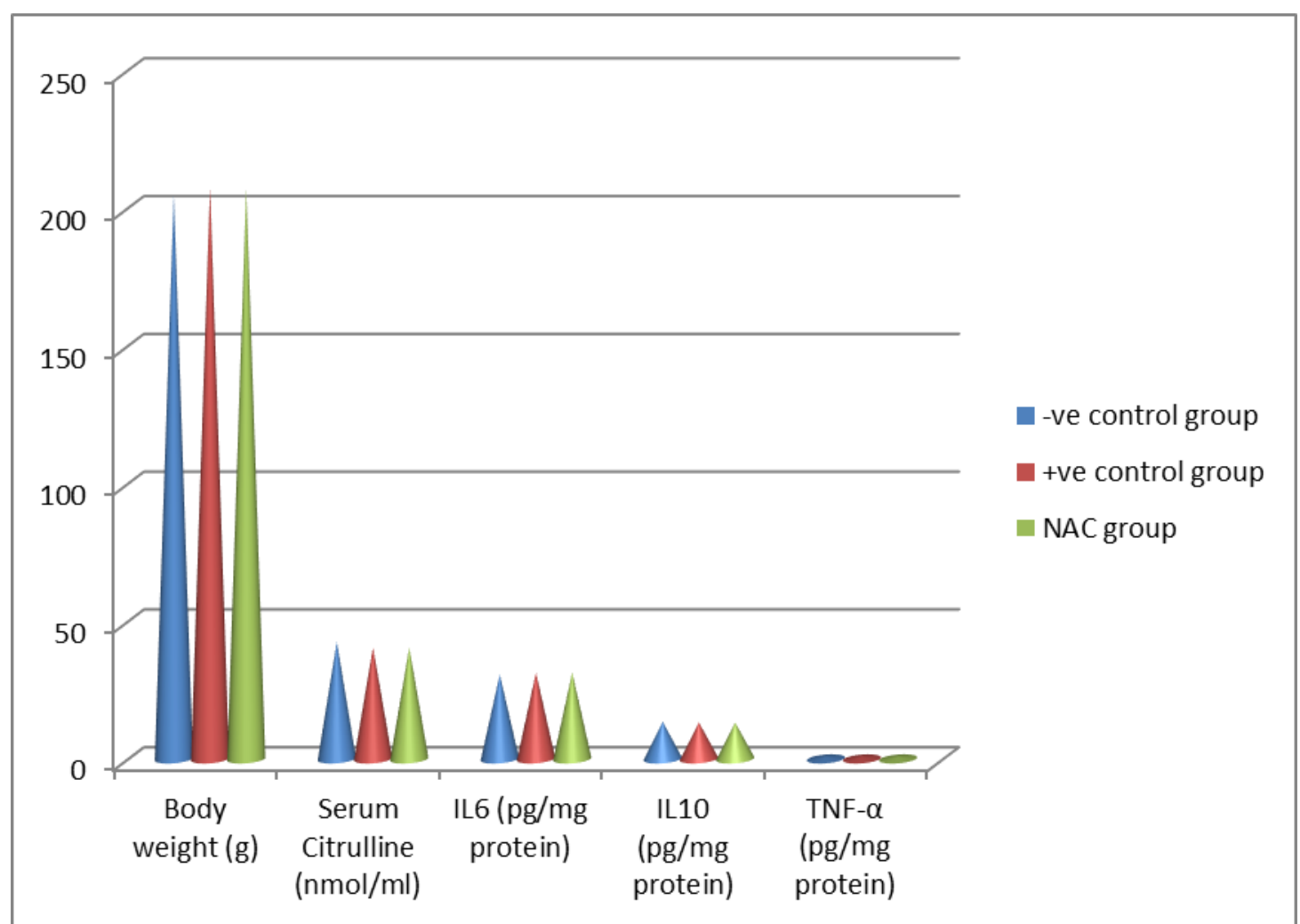

Figure 1 : Bar chart showing comparison between -ve control group , +ve control group and, NAC group as mean values of body weight, serum citrulline, levels of IL6, IL10 and TNF- $\alpha$ in ileum. Values obtained from rats treated for 6 weeks. Data expressed as Mean \pm SD (Number $=10$ rats/group).

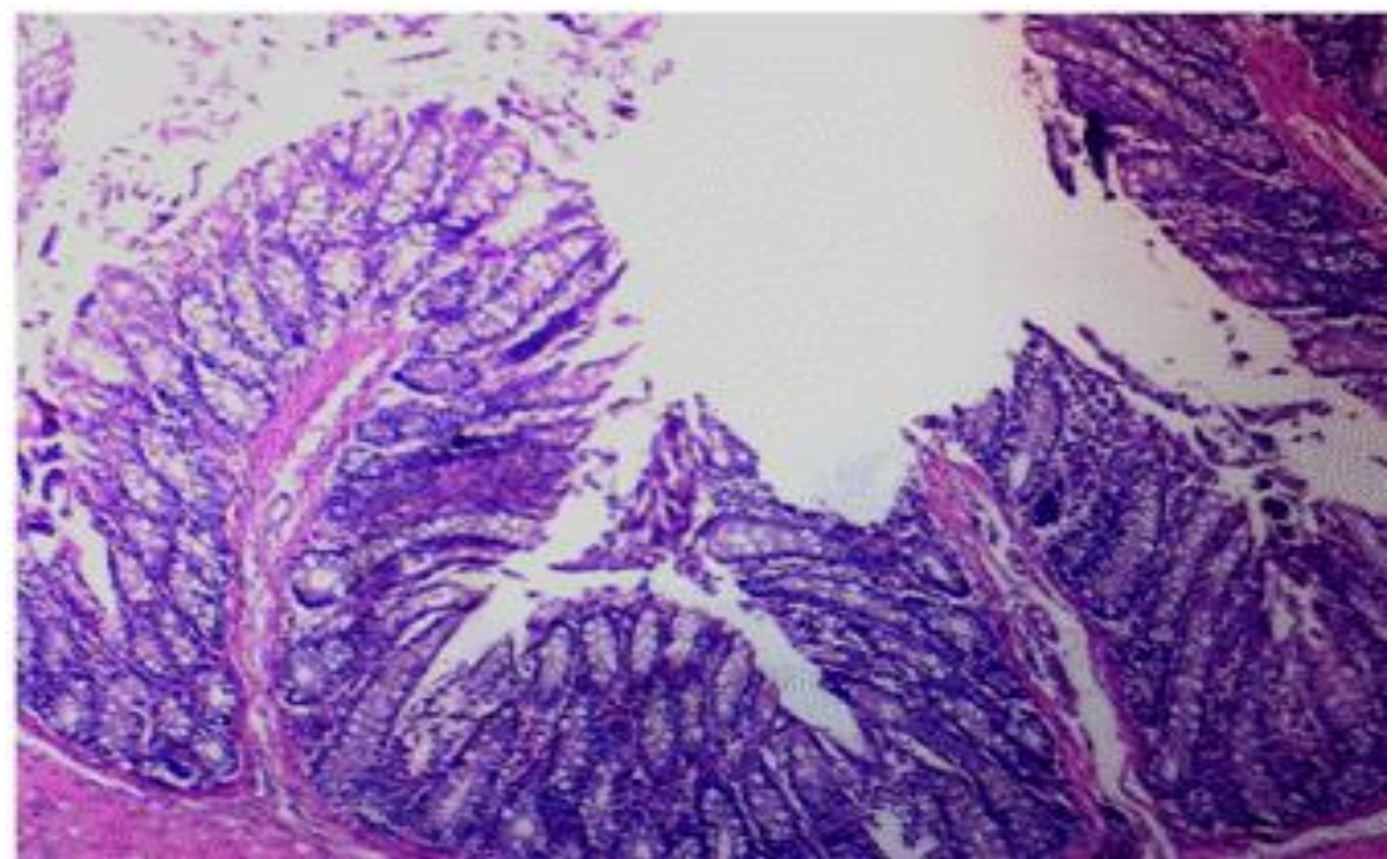

Figure 2: A photomicrograph of section in ileal tissues obtained from an adult male albino rat of control group showed normal histology (H\&E X200). 


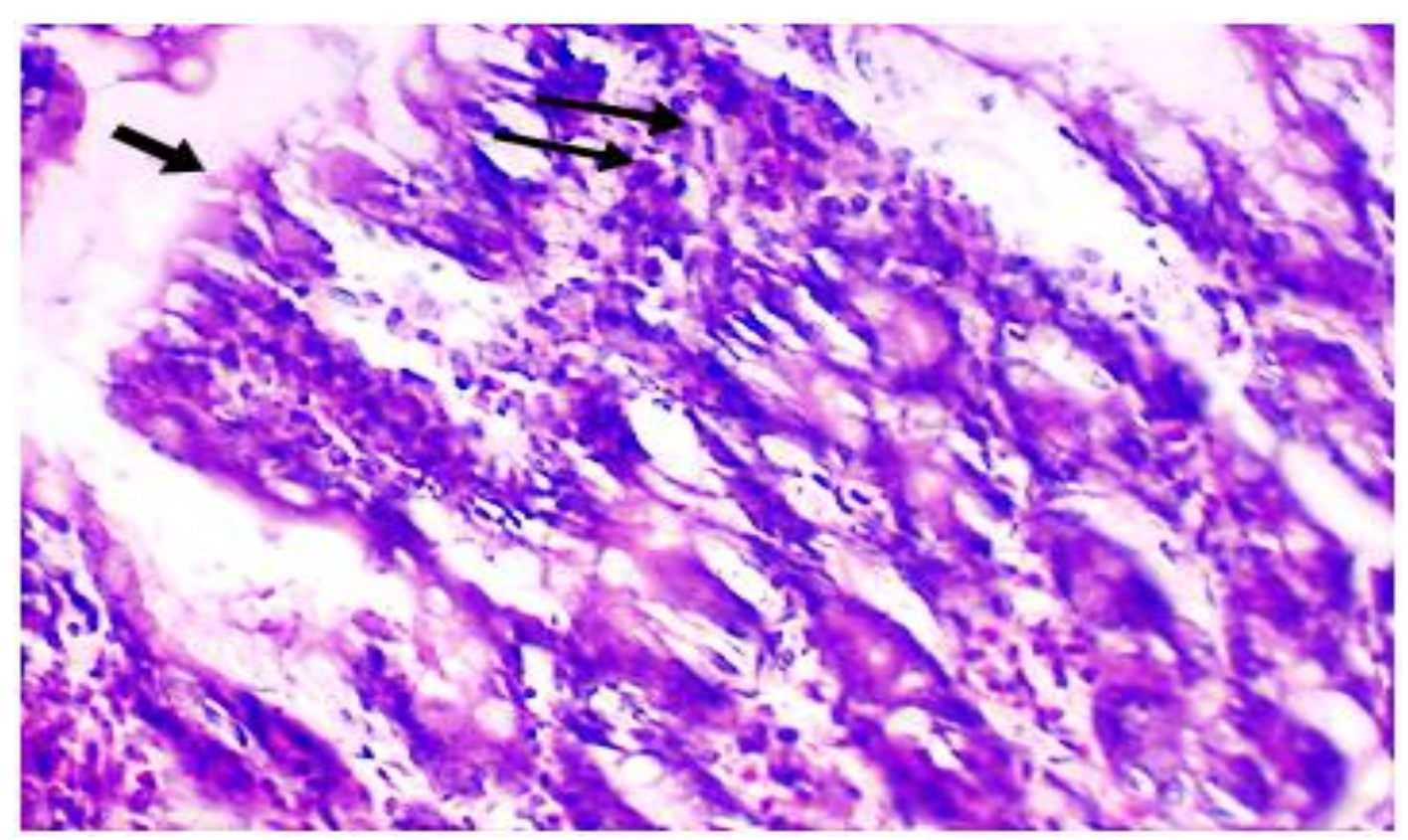

Figure 3: A photomicrograph of section of ileal tissue obtained from an adult male albino rat treated with $\mathrm{TiO}_{2}$ NPs showing atrophy of lining mucosa (arrow) with infiltration of mucosa and submucosa with inflammatory cells in form of lymphocytes, plasma cells and macrophages (double arrow) (H\&E X400).

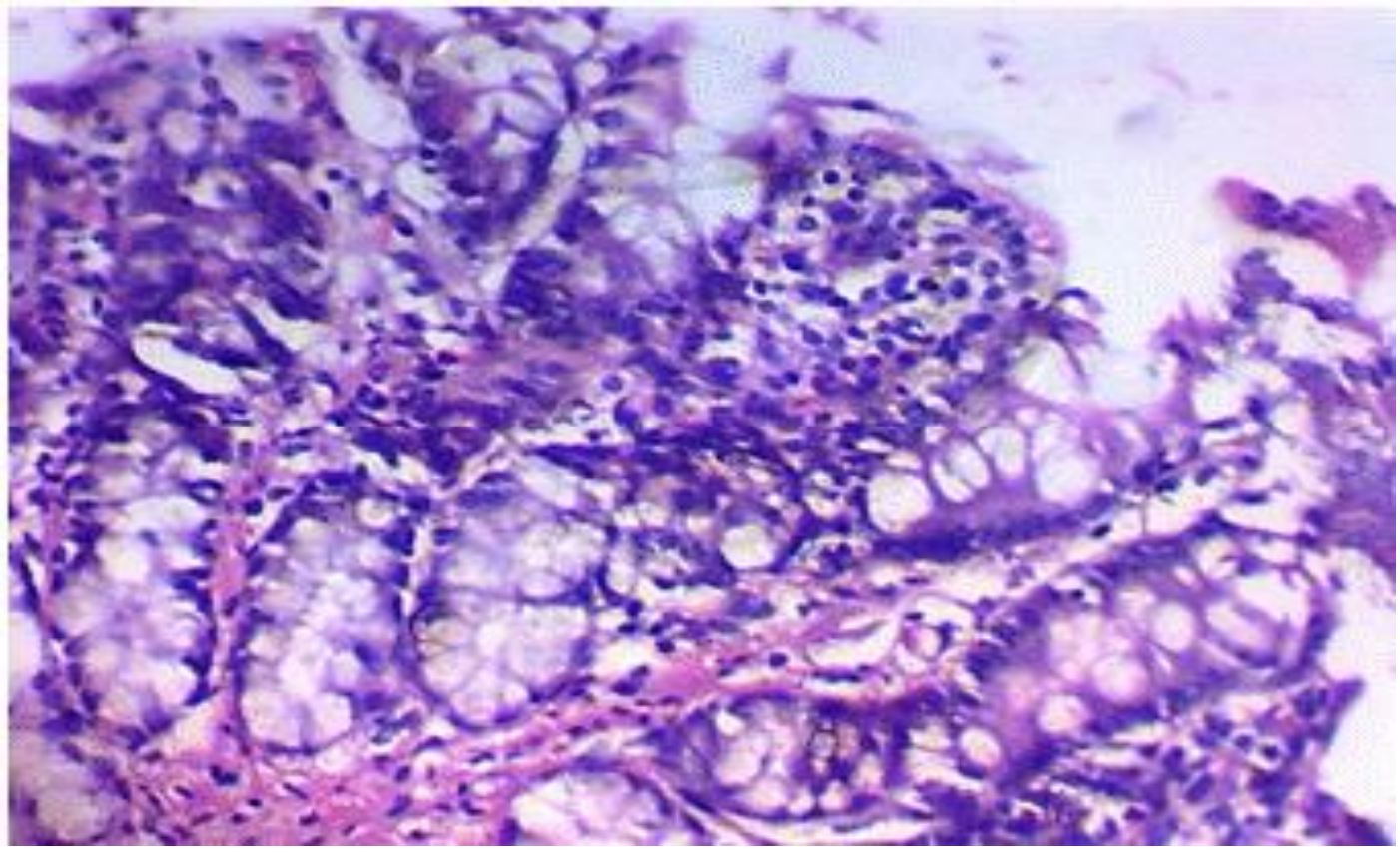

Figure 4: A photomicrograph of section in ileal tissue obtained from an adult male albino rat treated with $\mathrm{TiO}_{2} \mathrm{NPs}+\mathrm{NAC}$ showing regeneration of lining mucosa with decrease inflammatory cells infiltrate (H\&E X400). 


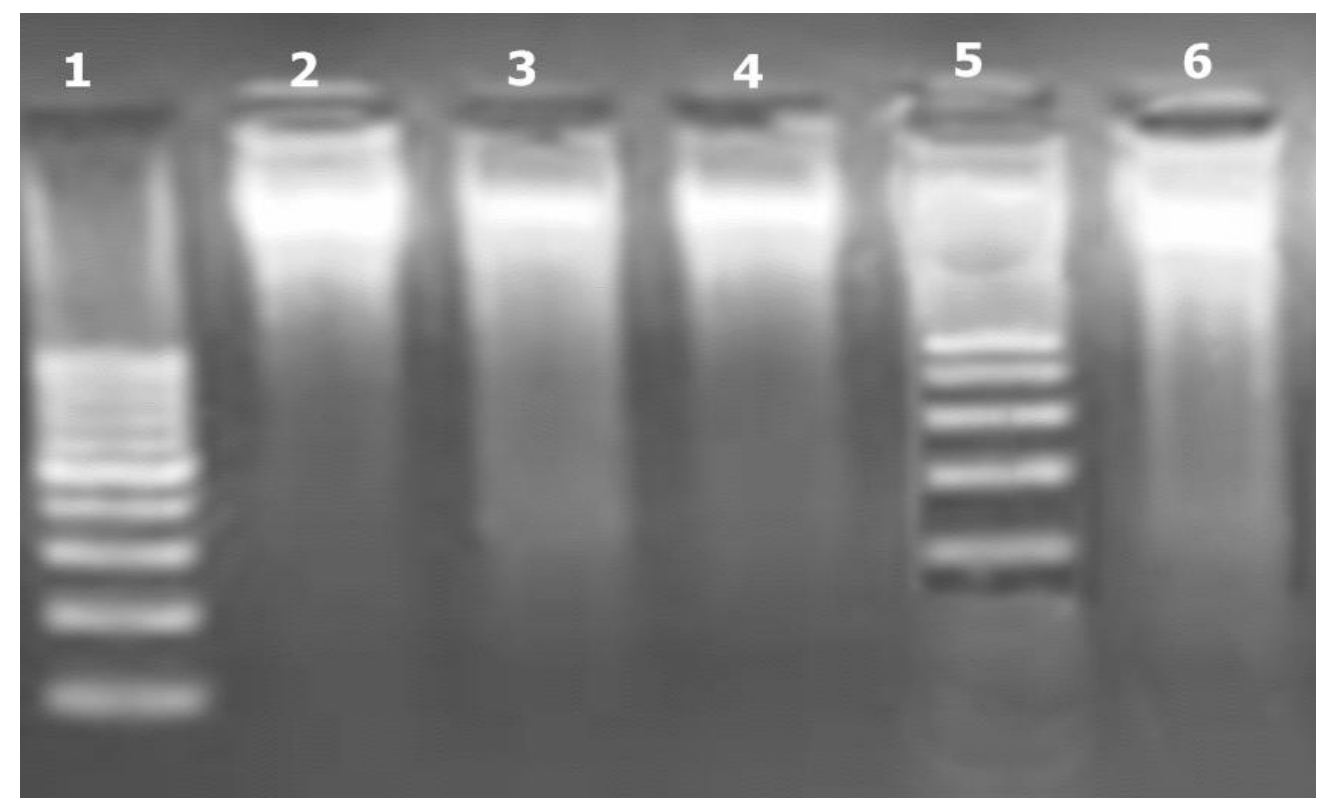

Figure 5 : Agarose gel electrophoresis of DNA isolated from ileal tissues of adult male albino rat showed:

Lane 1: 100bp size ladder.

Lane 2: no breakage of extracted DNA in (-ve) control group.

Lane 3: no breakage of extracted DNA in (+ve) control group.

Lane 4: no breakage of extracted DNA in NAC group.

Lane 5: fragmentation of extracted DNA as multiple bands in $\mathrm{TiO}_{2} \mathrm{NPs}_{\text {group. }}$

Lane 6: no breakage of extracted DNA in $\mathrm{TiO}_{2} \mathrm{NPs}+\mathrm{NAC}$ group.

\section{Discussion}

As a result of extensive use of nanotechnology, there is a progressive desire to evaluate the potential adverse effects and toxicities from these nanomaterials. There are many routes of exposure to these nanomarteials, but the oral route has an important consideration because of their extensive uses in food products and their widespread in environmental sources which may be another source of oral exposure. All these attract attention to study the effects of oral intake of $\mathrm{TiO}_{2} \mathrm{NPs}$ (Guo et al., 2017).

Small intestine is considered as an important site in which most nutrient digestion and absorption of different food types as carbohydrates, proteins, and fats occur. It provides as well secretory and protective immune functions. So that, disturbance in this complex system can result in multiple adverse effects (Bergin and Witzmann, 2013).

In our study, $\mathrm{TiO}_{2} \mathrm{NPs}$ administration significantly reduced body weight in rats, meanwhile, $\mathrm{TiO}_{2}$ NPs+NAC showed non significant changes in body weight.

These results are in line with those observed by Bermudez et al. (2002); Wang et al. (2007); ELSharkawy et al. (2010); Abu-Dief et al.(2015) and Shakeel et al. (2017). They found that $\mathrm{TiO}_{2} \mathrm{NPs}$ decreased body weight in the experimental animals. Bermudez et al. (2002) explained the decrease in body weight due to retention and overload of $\mathrm{TiO}_{2} \mathrm{NPs}$. Oberdorster et al. (2005) reported that $\mathrm{TiO}_{2} \mathrm{NPs}$ had difficulty in their excretion leading to increase $\mathrm{TiO}_{2}$ NPs retention half time. For example, in rat lung, halftime of fine particles of titanium dioxide (250 nm) was 117 days, while that of nanoparticles $(20 \mathrm{~nm})$ was 541 days. In a study by EL-Sharkawy et al. (2010), anorexia and disturbance in different metabolic systems was observed in $\mathrm{TiO}_{2} \mathrm{NPs}$ exposed animals which would be the cause of weight loss.

Citrulline is an amino acid classified as non essential one. It is a precursor for renal arginine production. Small intestine enterocytes is responsible for its synthesis (Rabier and Kamoun, 1995). Citrulline has been proposed, a biomarker of small intestinal enterocyte mass and function (Crenn et al., 2003 and Crenn et al., 2008). Recently, it has been considered as a good method to diagnose the intestinal disorders whatever the cause (Barzal et al., 2014) and a reliable marker for intestinal insufficiency either acute or chronic (Fragkos and Forbes, 2018).

In our study, serum level of citrulline was decreased after $\mathrm{TiO}_{2}$ NPs treatment and addition NAC caused partial protection against the adverse effects of $\mathrm{TiO}_{2}$ NPs.

This is consistent with Koeneman et al.(2010) who observed altered the microvilli of intestinal epithelium after $\mathrm{TiO}_{2}$ NPs exposure for 10 days. Also, Guo et al. (2017) found that in vitro chronic $\mathrm{TiO}_{2}$ NPs treatment decreased the number of intestinal microvilli leading to reduce the surface area that is necessary for nutrient absorption and transport. Moreover, changes in gene expression of nutrient transporter protein had taken place, supposed the role of intestinal cells to adjust the disruption in transport mechanisms which occurred by oral intake of nanoparticle. These effects showed impaired intestinal 
function and structure with significant decrement in absorption of iron, zinc and fatty acids.

It was found that $\mathrm{TiO}_{2} \mathrm{NPs}$ increased reactive oxygen species (ROS) formation leading to disruption of tight junction protein with significantly increased intestinal permeability (Chen et al., 2008; De Angelis et al., 2013 and Guo et al., 2017). In addition to oxidative stress, $\mathrm{TiO}_{2} \mathrm{NPs}$ increased proinflammatory cytokines like TNF- $\alpha$ causing intestinal inflammation with increasing its permeability (Katayama et al., 2006).

NAC is a precursor of glutathione which promotes detoxification and removal of ROS (Elgindy et al., 2010). Many studies demonstrate ameliorative effect of NAC against $\mathrm{TiO}_{2}$ NPs generating deleterious oxygen species in different organs (Xue et al., 2011; Attia et al., 2013; El-Kirdasy et al., 2014 and Elnagar et al., 2018). So, by reducing oxidative stress, NAC can improve intestinal barrier as shown by OZ et al. (2007).

Cytokines are proteins produced by immune cells, modulating immune response by affecting activity, differentiation and proliferation of other cells (Smith and Humphries, 2009). It is found that these cytokines have a significant role in the mechanisms of many diseases of intestinal tissues as infectious enterocolitis, celiac disease, eosinophilic gastroenteritis, irritable bowel syndrome, and inflammatory bowel disease, which is a severe form of intestinal inflammation (Ford and Talley, 2011 and Strober and Fuss, 2011).

In our study there were highly significant increases in IL6 and TNF- $\alpha$ and highly significant decrease in IL10 in ileal tissues in TiO2 NPs exposed rats compared to other groups. Adding NAC to $\mathrm{TiO} 2$ NPs provided protection against these changes induced by TiO2 NPs.

Many cells and tissues synthesis and release various cytokines following exposure to infection and/or toxicity as IL-6 and IL-10. IL-6 is one of interleukins that secreted by $\mathrm{T}$ lymphocytes and macrophages. It exerts an important role in induction of inflammation as it acts as pro-inflammatory cytokine (Smolen and Maini, 2006). On the same line, IL-10 works as a powerful anti inflammatory cytokine by inhibiting IL-6 secretion and down-regulates expression of Th1 cytokines (Fiorentino et al., 1991 and Pestka et al., 2004).

These results are similar to that of Nogueira et al. (2012) where male mice orally gavaged by $\mathrm{TiO}_{2}$ NPs for 10 days, showed significant increases in IL6 and TNF- $\alpha$ and decrease in IL10 in small intestines especially ileum proposing that $\mathrm{TiO}_{2} \mathrm{NPs}$ enhance inflammation basically in small intestine through Th1-mediated pathway.

Ileum represents the main site of nanoparticles uptake across the gastrointestinal tract as huge amount of Peyer's patches present in it (Florence, 1997). These data are confirmed by Li et al. (2009) who noticed that large concentations of nanoparticles were absorbed in ileum and colon of rats. These are matched with previous studies noticed accumulation of $\mathrm{TiO}_{2} \mathrm{NPs}$ in the intestine of rats (Jani et al., 1994) and fish (Zhang et al., 2007).
Accumulation of $\mathrm{TiO}_{2}$ NPs in Peyer's patches which are sites of lymphatic tissues aggregates in intestine, could have a role in the development of many adverse effects including inflammation that might participate in the incidence of inflammatory bowel disease (Lomer et al., 2002).

Kish et al. (2013) found an increase in expression of proinflammatory cytokines with changes in colon bacterial content after ingestion of small doses of $\mathrm{TiO}_{2} \mathrm{NPs}$ in mice. In addition, a study done by Bettini et al., (2017) in which, high levels of IL-6 and TNF- $\alpha$ in colon were revealed after chronic administration of small amounts of $\mathrm{TiO}_{2} \mathrm{NPs}$.

These results are in agreement with that of Guo et al. (2017) who stated that chronic administration of $\mathrm{TiO}_{2}$ NPs increase the expression of TNF- $\alpha$ gene in small intestine. TNF- $\alpha$ mediates the inflammation significantly by stimulating nuclear factor kappa-light-chain-enhancer of activated B cells $(\mathrm{NF}-\kappa \mathrm{B})$ that down regulates tight junction protein and changes its location (Ma et al., 2004). As a result, increased intestinal permeability and inflammation similar to that observed in Crohn's disease had occurred (Katayama et al., 2006 and Guo et al., 2017)

Soliman et al. (2013) and El-Kirdasy et al. (2014) notified increases in the expression of IL-6 and TNF- $\alpha$ in spleen and testes respectively after 3 months of $\mathrm{TiO}_{2}$ NPs utilization and addition of NAC induced normalization in the expression of these cytokines in rats. Also, Elnagar et al. (2018) found a reduction in the expression of TNF- $\alpha$ in testes of rats taken NAC with $\mathrm{TiO}_{2}$ NPs. All these observations confirm on the ability of NAC to stimulate immune system and ameliorate inflammatory effects enhanced by $\mathrm{TiO}_{2} \mathrm{NPs}$.

NAC has anti-inflammatory activity via modulation of proinflammatory cytokine synthesis and inhibition of NF- $\kappa \mathrm{B}$ through holding $\mathrm{I}-\kappa \mathrm{B}$ (an inhibitor of NF- $\kappa$ B) degradation (Berk et al., 2013). NAC is also known as a glutathione precursor that scavenges free radicals and prevents upstream NF- $\kappa \mathrm{B}$-activating events (Pei et al., 2018).

The biochemical changes of this work are confirmed by histopathological changes in ileum. There were atrophy of lining mucosa with infiltration of mucosa and submucosa with inflammatory cells in form of lymphocytes, plasma cells and machrophages in $\mathrm{TiO}_{2} \mathrm{NP}$ exposed rats while; NAC administrated with $\mathrm{TiO}_{2}$ NPs provided protection against these changes.

Butler et al. (2007) suggested the occurrence of inflammation in the mucosa of intestinal tissues after $\mathrm{TiO}_{2}$ NPs are taken up by immune cells. However, Nogueira et al. (2012) observed hypertrophy and hyperplasia in the mucosal epithelium in mice taken $\mathrm{TiO}_{2}$ NPs (100mg/kg) for 10 days. This difference may be related to differences in dose and duration of the study.

Human studies put insight on $\mathrm{TiO}_{2} \mathrm{NPs}$ accumulated in Peyer's patch of human beings that may be implicated in the inflammatory bowel disease pathogenesis (Hummel et al., 2014). Ruiz et al. (2017) found that ingestion of high doses of $\mathrm{TiO}_{2} \mathrm{NPs}$ 
aggravated dextran sulfate sodium-induced colitis by stimulating the nucleotide-binding oligomerisation domain receptor, pyrin domain containing (NLRP)3 inflammasome with induction of ROS and enhancing the permeability of intestine. This inflammasome has a key role in preservation of intestinal homeostasis and inflammation progress in intestinal tissues (Elia et al., 2015).

Genotoxicity of $\mathrm{TiO}_{2} \mathrm{NPs}$ has been extensively studied, since it was discovered the potential role of $\mathrm{TiO}_{2}$ NPs in induction of cancer (Chen et al., 2014).

In this study, $\mathrm{TiO}_{2}$ NPs group showed DNA fragmentation when compared to other groups, while administration of NAC with $\mathrm{TiO}_{2} \mathrm{NPs}$ showed no breakage of extracted DNA.

By using different cell lines, numerous studies showed the ability of $\mathrm{TiO}_{2} \mathrm{NPs}$ in inducing genotoxicity (Landsiedel et al., 2009; Singh et al., 2009; Turkez, 2011; Catalán et al., 2012; Ghosh et al., 2013; Tavares et al., 2014; Khan et al., 2015 and Patel et al., 2017). Also, multiple in vivo studies showed genotoxicity induced by $\mathrm{TiO}_{2} \mathrm{NPs}$ (Trouiller et al., 2009; Mohamed and Hussien, 2016 and El-Sheikh et al., 2016).

However, Bettini et al. (2017) didn't observe any DNA damage in intestinal tissues after 7 days of $\mathrm{TiO}_{2} \mathrm{NPs}$ ingestion excluding their ability to produce genotoxicity. These differences may be related to differences in the duration of the study.

There are two kinds of genotoxicity created by $\mathrm{TiO}_{2}$ NPs; primary genotoxicity in which there is no inflammation, and secondary genotoxicity in which, there is inflammation with excess ROS production that interact with DNA. $\mathrm{TiO}_{2}$ NPs enter the nucleus, react with the DNA and inhibit its replication causing direct primary genotoxicity. In addition, there is an indirect primary genotoxicity which includes increase in ROS production, interaction with nuclear proteins, antioxidant suppression, disruption of cell cycle check points or release of toxic ions from either soluble or poorly soluble NPs (Ong et al., 2014 and Golbamaki et al., 2015).

The diminished level of DNA damage observed in rats treated with NAC with $\mathrm{TiO}_{2} \mathrm{NPs}_{\text {was }}$ in parallel with that of Shi et al. (2013) who found a significant reduction in the level of DNA damage induced by $\mathrm{TiO}_{2}$ NPs after the usage of NAC in human lymphocytes. Also, Elnagar et al.(2018) showed a decrease in the degree of DNA destruction in testicular tissues after taken NAC with $\mathrm{TiO}_{2} \mathrm{NPs}$. By scaverging ROS, anti-inflammatory activity, immunological effects, induction of DNA repair, and effect on cell cycle progression, NAC can attenuate genotoxicity (Pei et al., 2018).

\section{Conclusion}

Oral administration of $\mathrm{TiO}_{2}$ NPs induced inflammation as well as DNA damage in the small intestinal tissue. NAC administration along with $\mathrm{TiO}_{2}$ NPs leads to a significant decrease in intestinal toxicity induced by $\mathrm{TiO}_{2}$ NPs. In addition, prevention of DNA damage proved by gel electrophoresis had occurred. Increasing the public awareness about the proper handling of
$\mathrm{TiO}_{2}$ NPs materials with periodical clinical and laboratory examinations are needed.

\section{Acknowledgments}

Great thanks to Dr. Mona Mostafa Ahmed, Lecturer of pathology, Zagazig University for her great help in histopathological slides.

\section{References}

Abu-Dief EE, Khalil KM, Abdel-Aziz HO, et al., (2015): Histological effects of Titanium dioxide nanoparticles in Adult male albino rat liver and possible prophylactic effects of Milk thistle seeds. Life Sci. J. 12(2):115-123.

Amsen D, de Visser KE and Town T. (2009): Approaches to Determine Expression of Inflammatory Cytokines. Methods Mol. Biol. 511: 107-142.

Attia HF, Soliman MM, Abdel-Rahman GH, et al., (2013): Hepatoprotective Effect Of NAcetylcystiene On The Toxic Hazards Of Titanium Dioxide Nanoparticles. Amer.J. Pharm. Toxicol. 8 (4): 141-147.

Barzał JA, Szczylik C, Rzepecki P, et al., (2014): Plasma citrulline level as a biomarker for cancer therapy-induced small bowel mucosal damage, Acta. Biochemica. Polanica. 61(4):615:631.

Bergin LL and Witzmann FA (2013): Nanoparticle toxicity by the gastrointestinal route: evidence and knowledge gaps. Int. J. Biomed. Nanosci. Nanotechnol. 3:1-2.

Berk M, Malhi GS, Gray LJ, et al., (2013): "The promise of $\mathrm{N}$-acetylcysteine in neuropsychiatry," Trends in Pharmacological Sciences. 34(3): 167-177.

Bermudez E, Mangum J B, Asgharian B, et al., (2002): Long-term pulmonary responses of three laboratory rodent species to subchronic inhalation of pigmentary titanium dioxide particles. Toxicol. Sci. 70: 86-97.

Bettini1 S, Boutet-Robinet E, Cartier C, et al., (2017): Food-grade $\mathrm{TiO}_{2}$ impairs intestinal and systemic immune homeostasis, initiates preneoplastic lesions and promotes aberrant crypt development in the rat colon. scientific reports. 7:40373.

Burton K (1956): A study of the conditions and mechanism of the diphenylamine reaction for the colorimetric estimation of deoxyribonucleic acid. Biochem. J. 62: 315327.

Butler M, Boyle J J, Powell J J, et al., (2007): Dietary microparticles implicated in Crohn's disease can impair macrophage phagocytic activity and act as adjuvants in the presence of bacterial stimuli. Inflamm. Res.56:353-361.

Catalán J, Järventaus H, Vippola M, et al., (2012): Induction of chromosomal aberrations by carbon nanotubes and titanium dioxide nanoparticles in human lymphocytes in vitro. Nanotoxicol. 6:825-836.

Chen L, Yokel RA, Hennig B, et al., (2008): Manufactured Aluminum Oxide Nanoparticles 
Decrease Expression of Tight Junction Proteins in Brain Vasculature. J. Neuroimmun. Pharmacol.3:286-295.

Chen T, Yan J and Li Y (2014): Genotoxicity of titanium dioxide nanoparticles. J. food and drug anal. 22(1):95-104.

Crenn P, Messing B and Cynober L.(2008): Citrulline as a biomarker of intestinal failure due to enterocyte mass reduction. Clin. Nutr. 27(3):328-339.

Crenn P, Vahedi K, Lavergne-Slove A, et al.,(2003): Plasma citrulline: A marker of enterocyte mass in villous atrophy-associated small bowel disease. Gastroenterol.124(5):12101219.

De Angelis I, Barone F, Zijno A, et al., (2013): Comparative study of $\mathrm{ZnO}$ and $\mathrm{TiO} 2$ nanoparticles: physicochemical characterisation and toxicological effects on human colon carcinoma cells. Nanotoxicol.7:1361-1372.

Elgindy EA, El-Huseiny AM, Mostafa MI, et al., (2010): N-acetyl cysteine: could it be an effective adjuvant therapy in ICSI cycles?. A preliminary study. Reprod. Biomed. Online. 20(6):789-796.

Elia PP, Tolentino Y F, Bernardazzi C, et al., (2015): The role of innate immunity receptors in the pathogenesis of inflammatory bowel disease. Mediators Inflamm. 936193 (2015).

El-Kirdasy AF, Nassan MA, Baiomy AA, et al., ( 2014): Potential Ameliorative Role Of NAcetylcysteine Against Testicular Dysfunction Induced By Titanium Dioxide In Male Albino Rats. Amer. J. Pharm.Toxicol. 9(1): 29-38.

Elnagar AMB, Ibrahim A and Soliman AM (2018): Histopathological effects of titanium dioxide nanoparticles and the possible protective role of $\mathrm{N}$-acetylcysteine on the testes of male albino rats. Int. J. Fertil. Steril. 12(3): 249256.

EL-Sharkawy NI, Hamza SM and Abou-Zeid EH (2010): Toxic Impact of Titanium Dioxide $\left(\mathrm{TiO}_{2}\right)$ In Male Albino Rats with Special Reference to its Effect on Reproductive System. J.Amer.Sci. 6(11):865-872.

El-Sheikh AA, Ameen SH, Ibrahim HM, et al., (2016): The immunotoxic effects of short term chronic exposure to Titanium Dioxide Nanoparticles on spleen of adult albino rats and the role of after toxic effect follow up. Ain Shams Journal of Forensic Medicine and Clinical Toxicol. 26: 115- 128.

Fiorentino DF, Zlotnik A, Mosmann TR et al., (1991): IL-10 inhibits cytokine production by activated macrophages. J. Immunol.147(11):3815-22.

Florence AT (1997): The oral absorption of micro- and nanoparticulates: neither exceptional nor unusual. Pharm. Res. 14:259-266.

Ford AC and Talley NJ (2011): Mucosal inflamation as a potential etiolog-ical factor in irritable bowel syndrome: A systematic review. J. Gastroenterol. 46:421-31.

Fragkos KC and Forbes A (2018): Citrulline as a marker of intestinal function and absorption in clinical settings: A systematic review and meta-analysis. United Eur. Gastroenterol. J. 6(2): 181-191.

Ghosh M, Chakraborty A and Mukherjee A (2013): Cytotoxic, genotoxic and the hemolytic effect of titanium dioxide ( $\mathrm{TiO} 2)$ nanoparticles on human erythrocyte and lymphocyte cells in vitro. J. Appl. Toxicol. 33:1097-1110.

Golbamaki N, Rasulev B, Cassano A, et al., (2015): Genotoxicity of metal oxide nanomaterials: review of recent data and discussion of possible mechanisms. Nanoscale. 7:21542198.

Grande F and Tucci P (2016): Titanium dioxide nanoparticles: a risk for human health? Mini Rev. Med. Chem. 16(9):762- 769.

Gui S, Zhang Z, Zheng L, et al., (2011): "Molecular mechanism of kidney injury of mice caused by exposure to titanium dioxide nanoparticles," J. Hazardous Materials. 195: 365-370.

Guo Z, Martucci NJ, Moreno-Olivas F, et al., (2017): Titanium Dioxide Nanoparticle Ingestion Alters Nutrient Absorption in an In Vitro Model of the Small Intestine. NanoImpact. 5: 70-82.

Horobin, R. W. and Bancroft, J. D. (1998): Hematoxylin and Eosin as an oversight stain In: Trouble Shooting Histology Stains. $1^{\text {st }}$ ed., Chapter (22), Churchill living stone, Pearson Professional Limited press, New York, London and Madrid, 88 - 93.

Hummel TZ, Kindermann A, Stokkers PC, et al.,(2014): Exogenous pigment in Peyer patches of children suspected of having IBD. J. Pediatr. Gastroenterol. Nutr. 58: 477-480.

Institute of laboratory animals resources (ILAR), Commission on life sciences, National research council (1996). Guide for the care and use of laboratory animals. National academy press.

Jain S, Kumar CH M, Suranagi UD, et al., (2011): "Protective effect of Nacetylcysteine on bisphenol A-induced cognitive dysfunction and oxidative stress in rats". Food and Chem. Toxicol. 49: 1404-1409.

Jani PU, McCarthy DE and Florence AT (1994): Titanium dioxide (rutile) particle uptake from the rat GI tract and translocation to systemic organs after oral administration. Int. J. Pharm. 105:157-168.

Joslin, J. (2009): Blood collection: Techniques in exotic small mammals. J. Exotic. Pet. Med., 18(2): 117-139.

Katayama S, Xu X, Fan MZ, et al., (2006): Antioxidative Stress Activity of Oligophosphopeptides Derived from Hen Egg Yolk Phosvitin in Caco-2 Cells. J.Agri. and Food Chem.54:773-778. 
Khan M, Naqvi AH and Masood A (2015): Comparative study of the cytotoxic and genotoxic potentials of zinc oxide and titanium dioxide nanoparticles. Toxicol. Rep. 2:765-774.

Kish L, Hotte N, Kaplan GG, et al., (2013): Environmental particulate matter induces murine intestinal inflammatory responses and alters the gut microbiome. PLoS One. 2013, 8:e62220.

Koeneman BA, Zhang Y, Westerhoff P, et al., (2010): Toxicity and cellular responses of intestinal cells exposed to titanium dioxide. Cell Biol. and Toxicol. 26:225-238.

Landsiedel R, Kapp MD, Schulz M, et al., (2009): Genotoxicity investigations on nanomaterials: methods, preparation and characterization of test material, potential artifacts and limitations-many questions, some answers. Mutat. Res. 681:241-258.

Larsson SC, Håkansson N and Wolk A (2015): Dietary cysteine and other amino acids and stroke incidence in women. Stroke. 46(4):922-926.

Li H, Zhao X, Ma Y, et al., (2009): Enhancement of gastrointestinal absorption of quercetin by solid lipid nanoparticles. J. Control Release. 133:238-244.

Lomer MC, Thompson RP and Powell JJ (2002): Fine and ultrafine particles of the diet: influence on the mucosal immune response and association with Crohn's disease. Proc. Nutr. Soc. 61:123130.

Ma TY, Iwamoto GK, Hoa NT, et al., (2004): TNF- $\alpha-$ induced increase in intestinal epithelial tight junction permeability requires NF- $\kappa \mathrm{B}$ activation. Amer. J. Phys. Gastrointes. and Liver Physiol. 286:G367-G376.

Migdal C, Rahal R, Rubod A, et al., (2010): Internalisation of hybrid titanium dioxide/para-amino benzoic acid nanoparticles in human dendritic cells did not induce toxicity and changes in their functions. Toxicol. Lett. 199(1):34-42.

Mohamed HRH and Hussien NA. (2016): Genotoxicity Studies of Titanium Dioxide Nanoparticles $\left(\mathrm{TiO}_{2} \mathrm{NPs}\right.$ ) in the Brain of Mice. Volume 2016, Article ID 6710840, 7 pages. http://dx.doi.org/10.1155/2016/6710840

Mokhtari V, Afsharian P, Shahhoseini M, et al. (2017): A Review on Various Uses of NAcetyl Cysteine. Cell J.19(1): 11-17.

Nogueira CM, de Azevedo WM, Dagli ML, et al., (2012): Titanium dioxide induced inflammation in the small intestine. World J. Gastroenterol. 18:4729-4735.

Oberdorster G, Oberdorster E and Oberdorster J (2005): Nanotoxicology: an emerging discipline evolving from studies of ultrafine particles. Environ. Health Perspect,113: 823839.

Ong KJ, MacCormack TJ, Clark RJ, et al., (2014): Widespread nanoparticle-assay interference: implications for nanotoxicity testing. PLoS ONE. 9:e90650.

OZ S, Okay E, Karadenizli A, et al., (2007): NAcetylcysteine Improves Intestinal Barrier In Partially Hepatectomized Rats. ANZ . J. Surg. 77: 173-176.

Park EJ, Yi J, Chung KH, et al., (2008): Oxidative stress and apoptosis induced by titanium dioxide nanoparticles in cultured BEAS-2B cells. Toxicol. Lett. 180(3):222-229.

Patel S, Patel P and Bakshi SR (2017):Titanium dioxide nanoparticles: an in vitro study of DNA binding, chromosome aberration assay, and comet assay. Cytotechnol. 69(2): 245263.

Pei Y, Liu H, Yang Y, et al., (2018): Biological Activities and Potential Oral Applications of N-Acetylcysteine: Progress and Prospects. Oxidative Medicine and Cellular Longevity.Volume 2018, Article ID 2835787, 14 https://doi.org/10.1155/2018/2835787.

Perandones CE, lllera AV, Peckham D, et al., (1993): Regulation of apoptosis in vitro in mature murine spleen T-cell. J. Immunol. 151: 35213529.

Pestka S, Krause CD, Sarkar D, et al., (2004): Interleukin-10 and related cytokines and receptors. Annu. Rev. Immunol. 22: 929-979.

Rabier D and Kamoun P (1995): Metabolism of citrulline in man. Amino Acids. 9:299-316.

Ruiz PA, Morón B, Becker HM, et al.,(2017): Titanium dioxide nanoparticles exacerbate DSS-induced colitis: role of the NLRP3 inflammasome. Gut .66:1216-1224.

Shah SNA, Shah Z, Hussain M, et al., (2017): Hazardous Effects of Titanium Dioxide Nanoparticles in Ecosystem. Bioinorganic Chemistry and Applications. Article ID 4101735, 12 pages. Available at: https://doi.org/10.1155/2017/4101735.

Shakeel M, Jabeen F, Iqbal R, et al., (2017): Assessment of Titanium Dioxide Nanoparticles (TiO2-NPs) Induced Hepatotoxicity and Ameliorative Effects of Cinnamomum cassia in SpragueDawley Rats. Biological Trace Element Research. Available at: https://doi.org/10.1007/s12011-017-10743.

Shakeel M, Jabeen F, Shabbir S, et al., (2016): Toxicity of nano-titanium dioxide (TiO2-NP) through various routes of exposure: a review. Biol. Trace Elem. Res.172(1):1- 36.

Shi H, Magaye R, Castranova V, et al., (2013): Titanium dioxide nanoparticles: a review of current toxicological data. Part Fibre Toxicol. 10: 15.

Singh N, Manshian B, Jenkins GJ, et al., (2009): NanoGenotoxicology: the DNA damaging potential of engineered nanomaterials. Biomaterials. 30:3891-3914.

Smith AJ and Humphries SE (2009): Cytokine and cytokine receptor gene polymorphisms and 
their functionality. Cytokine Growth Factor Rev. 20:43-59.

Smolen JS and Maini RN (2006): Interleukin-6: A new therapeutic target. Arthritis Res. Ther. 8: S5S5.

Soliman MM, Attia HF, Hussein MM, et al., (2013): Protective Effect Of N-Acetylcystiene Against Titanium Dioxide Naonparticles Modulated Immune Responses In Male Albino Rats . Amer. J. Immunol. 9 (4): 148-158.

Strober W and Fuss IJ (2011): Proinflammatory cytokines in the patho-genesis of inflammatory bowel diseases. Gastroenterol. 140:1756-67.

Sund J, Palomäki J, Ahonen N, et al., (2014): Phagocytosis of nano-sized titanium dioxide triggers changes in protein acetylation. J. Proteo. 108:469-483.

Tavares AM, Louro H, Antunes S, et al., (2014): Genotoxicity evaluation of nanosized titanium dioxide, synthetic amorphous silica and multiwalled carbon nanotubes in human lymphocytes. Toxicol. In Vitro. 28:60-69.

Trouiller B, Reliene R, Westbrook A, et al., (2009): "Titanium dioxide nanoparticles induce DNA damage and genetic instability in vivo in mice," Cancer Research. 69(22): 8784-8789.
Turkez H (2011): The role of ascorbic acid on titanium dioxide-induced genetic damage assessed by the comet assay and cytogenetic tests. Exp. Toxicol. Pathol. 63:453-457.

Wang J, Zhou G, Chen C, et al., (2007): Acute toxicity and biodistribution of different sized titanium dioxide particles in mice after oral administration . Toxicol. Lett. 168: 176-185.

Waring WS. (2012): Criteria for acetylcysteine treatment and clinical outcomes after paracetamol poisoning. Expert Rev. Clin. Pharmacol. 5:311-318.

Xue C, Liu W, Wu J, et al., (2011): Chemoprotective effect of N-acetylcysteine (NAC) on cellular oxidative damages and apoptosis induced by nano titanium dioxide under UVA irradiation. Toxicol. In Vitro. 25(1):110-6.

Yang Y, Qina Z, Zenga W, et al., (2017): Toxicity assessment of nanoparticles in various systems and organs . Nanotechnol. Rev. 6(3): 279-289.

Youssef G, Meguid Ali A, Alaa N, et al., (2006): Nacetyl-cysteine in anovulatory women: the impact of postcoital test. Middle East Fertil . Soc. J.11:109-112.

Zhang X, Sun H, Zhang Z, et al., (2007): Enhanced bioaccumulation of cadmium in carp in the presence of titanium dioxide nanoparticles. Chemosphere. 67:160-166.

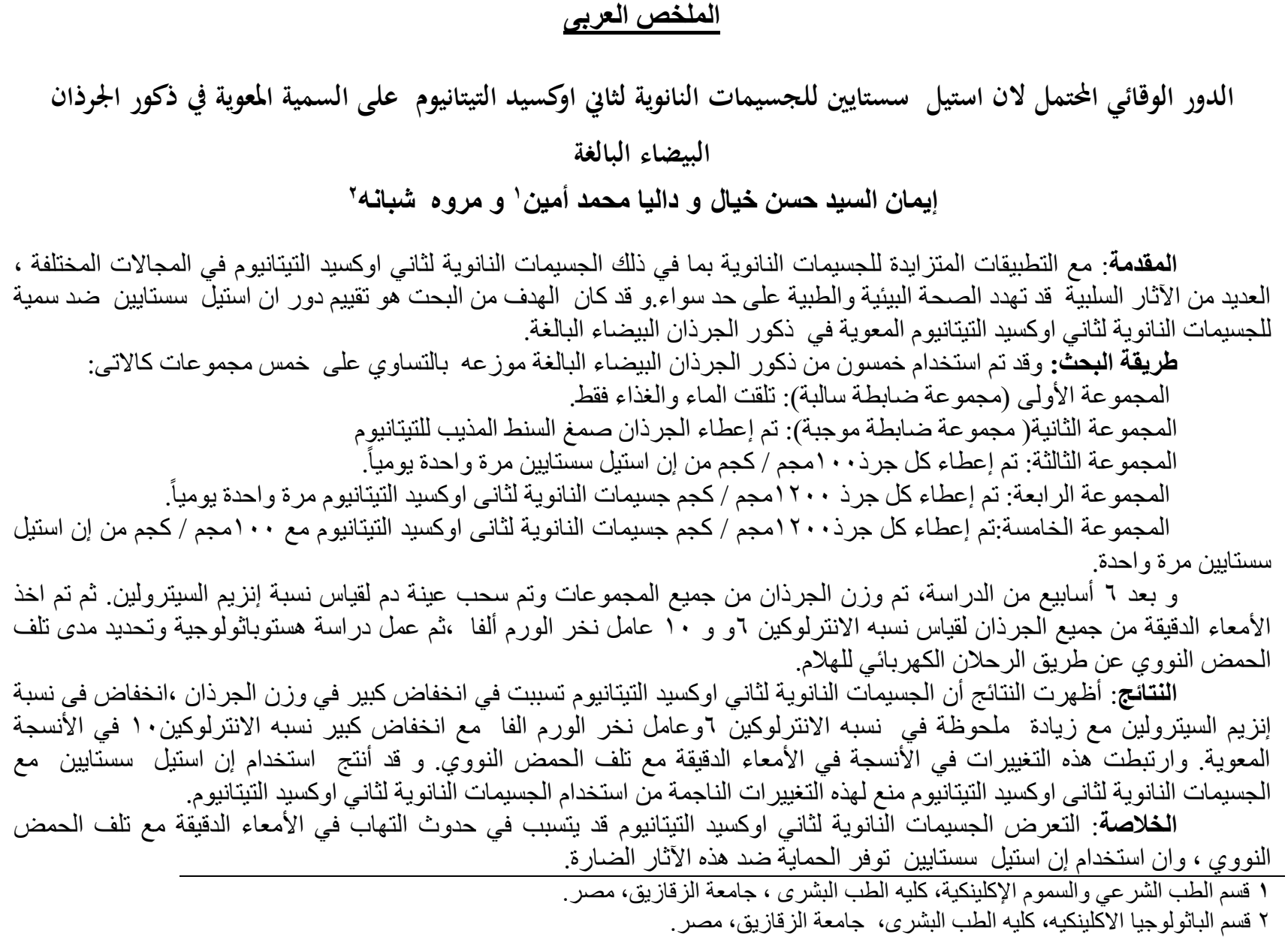

